\title{
Social Capital in the Scandinavian Countries
}

Andersen, Rasmus Fonnesbæk; Dinesen, Peter Thisted

Published in:

Routledge Handbook of Scandinavian Politics

Publication date:

2017

Document version

Peer reviewed version

Citation for published version (APA):

Andersen, R. F., \& Dinesen, P. T. (2017). Social Capital in the Scandinavian Countries. In P. Nedergaard, \& A. Wivel (Eds.), Routledge Handbook of Scandinavian Politics (pp. 161-173). Routledge. Routledge International Handbooks 


\title{
Social Capital in the Scandinavian Countries
}

\author{
Rasmus Fonnesbæk Andersen and Peter Thisted Dinesen. \\ Dept. of Political Science, University of Copenhagen
}

Forthcoming in Routledge Handbook on Scandinavian Politics edited by Peter Nedergaard \& Anders Wivel.

\section{Introduction}

The Nordic countries are admired worldwide for their social harmony. They are perhaps the prime example of Lijphart's "kinder, gentler" consensus democracies, displaying high economic and gender equality, extremely low corruption, generous foreign aid, and notable democratic satisfaction (Lijphart 1999). One of the most striking components of this 'societal gentleness' is the way citizens relate to and act towards each other, or what we may call the 'social capital' possessed by these societies. More specifically, they are 'cohesive' societies, wherein most citizens adopt cooperative attitudes towards others, refrain from crime and anti-social activities such as littering or other inconsiderate behaviours, uphold norms in the public sphere, and organise in voluntary associations to cultivate their common interests.

In this chapter, we conceptualise social capital as the strength of bonds between people who do not know each other. ${ }^{1}$ This definition sees social capital as collective in nature, but also as a societal aggregate of individuals' relations, behaviour and attitudes. Two prominent components of social capital are citizens' engagement in associations or voluntary work (sometimes called the "structural" component), and their beliefs and expectations about cooperation and trustworthiness of others (often referred to as the "attitudinal" component) (Putnam 1993; Rothstein and Stolle 2003). Scholars typically study individuals to examine engagement in associations and/or social trust (i.e. trust in unknown others), and we will therefore primarily rely on this type of research. By aggregating these individual attributes for a given community, we can then also study social capital as a communal phenomenon.

While there is still great disagreement on the causes of social capital, its effects are somewhat less disputed. Trust and community connectedness are widely regarded as facilitating collective action by lowering monitoring costs of informal social control, and increasing cooperative tendencies and altruistic preferences (Putnam 1993). As a consequence, social capital has been shown to lower crime (Kennedy et al. 1998; Lederman et al. 2002; Buonnano et al. 2009), lead to better health outcomes (Islam et al. 2006), further economic growth (Helliwell and Putnam 1995; Knack and Keefer 1997; Tabellini 2010), and lower corruption (Bjørnskov 2011). The political effects of social capital are

\footnotetext{
${ }^{1}$ We do not review research on social capital in the Bourdieudian sense. In this vein of research, a primary concern is the effect of social networks and contacts with respect to social mobility (see Bourdieu 1986; Portes 1998).
} 
perhaps most controversial: Some authors have found that it increases the responsiveness of democracy (Putnam 1993; Boix and Posner 1998; Nannicini et al. 2013), while others have found that social capital under certain circumstances also stabilises authoritarian rule (Jamal 2008; Acemoglu et al. 2014) or has even led to the breakdown of democracy (Berman 1997; Satyanath et al. forthcoming).

The concept of social capital has also entered the political discourse in the Nordic countries (and elsewhere). In Denmark, Sweden and Norway, the question of social cohesion-a close relative of social capital-has given rise to legislation and public debate. ${ }^{2}$ Nordic politicians even justify policies based on arguments about how to best maintain and build up high levels of social trust. However, as we will discuss, scholars of trust and civic life still debate exactly how social capital can be strengthened and what are the roots of social capital, in the Nordic context and elsewhere.

\section{Social Capital in the Nordic Countries}

\section{Stocks of social capital}

In the following, we first review existing research on patterns of social capital in the Nordic countries, in general as well as in the specific countries. Then, to provide an up-to-date overview, we present figures mapping two of the most frequently used indicators of social capital-social trust and doing organisational work-for recent data for the Nordic countries, as well as large European countries in order to situate the Nordic level of social capital.

As indicated in the Introduction, the Nordic countries are generally considered high scorers on various measures of social capital. Illustrative of this, Delhey and Newton (2005), in their examination of cross-country differences in social trust, show that the Nordic countries display among the highest levels of trust in the world in the early to mid-1990's, and attribute this "exceptionalism" to the countries' high scores on a range of characteristics known to be conducive to trust (cf. below). Other cross-country studies show a similar pattern, which also seems to have persisted into the $21^{\text {st }}$ century (Adam 2008; Bjørnskov 2008; Rothstein and Stolle 2003).

In Figure 1, we have plotted the level of social trust in the Nordic countries, as well as the largest European countries, in 2012 based on the European Social Survey (www.europeansocialsurvey.org). To measure trust, we have used the frequently employed question "Would you say that most people can be trusted, or that you can't be too careful in dealing with people?", scaled from 0 to 10 , where 10 reflects higher trust. ${ }^{3}$

\footnotetext{
${ }^{2}$ In Norway, from 2000 to 2011, "social capital" was used in 11 different reports by panels appointed by the Norwegian government (Norges offentlige utredninger, NOUs) and 8 statements from the government to the Norwegian Parliament (stortingsmeldinger), see Wollebæk \& Seegaard (2011).

3 This more fine-grained, continuous measure of trust provides a more nuanced and valid measure of trust than the dichotomous variable used in much previous work (Lundmark et al. forthcoming; Zmerli \& Newton 2008). It also accounts for the less pronounced differences in trust observed between countries (Adam 2008). The singleitem trust measure is often combined with two other items, tapping helpfulness and fairness, respectively, to form a trust scale. Employing this measure we obtain an essentially identical pattern to that reported in Figure 1.
} 


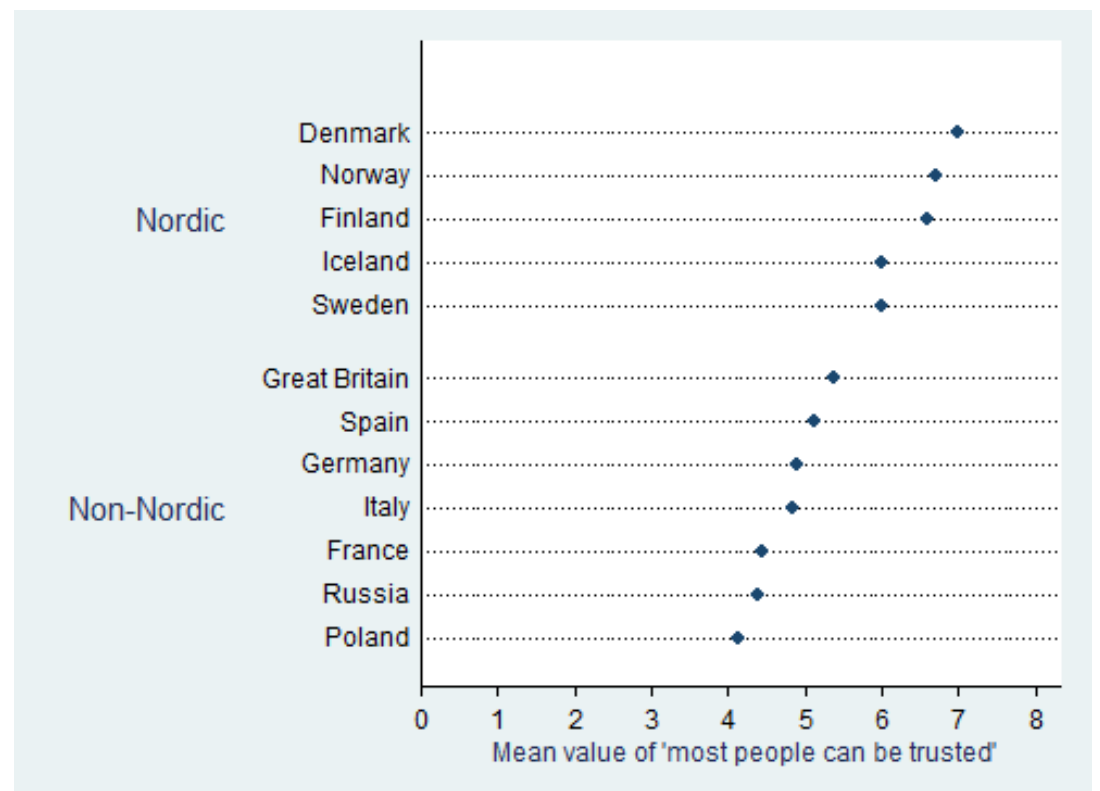

Figure 1: Social trust in the Nordic countries and the largest European countries (source: European Social Survey 2012, design weight applied).

The figure confirms previous results: the five Nordic countries display higher levels of social trust than the seven other countries. Denmark leads, with Norway and Finland in the middle, and Sweden and Iceland at the bottom among the Nordic countries. The data also allow us to break down the Finnish figures separately for the Aaland islands (as the only Nordic dependency) for the years of 2010, 2012 and 2014 (to increase the sample size). In this period the Aaland island displayed an average trust score of about 6.5, thus conforming with the level in Finland and the other Nordic countries. Among the non-Nordic countries, Great Britain has the highest and Poland the lowest level of trust. There is also important variation between the Nordic countries: the difference between Denmark (6.98) and Sweden (6.00) is actually greater than that between Sweden and Spain (5.13). ${ }^{4}$ These figures do something to nuance the picture of Nordic exceptionalism in social trust. While the Nordic countries all have high levels of trust comparatively speaking, there seem to be relatively marked differences within the Nordic bloc. In that sense, the Nordic countries seem to be high scorers on a continuum from high to low trust in Europe, rather than a homogenous cluster of very high-trust societies that are qualitatively different from the other European countries.

Turning to participation in civic life, the Nordic countries again come out as ranking relatively high in international comparisons. However, they are less distinctive than for social trust, and there is some variation across specific indicators (Adam 2008; Gesthuizen et al. 2009; Morales and Geurts 2007; Schofer and Fourcade 2001; Sivesind and Selle 2010). Here, rather than Nordic exceptionalism, the pattern seems to be one of the Northern European countries more generally, as well as the US and Canada, standing out as being the most civic. Figure 2, which maps the share of the population indicating having worked "to improve things" in a non-political organisation or association within the last 12 months based on the 2012 European Social Survey, tells a similar story. Using this indicator, Iceland is in the lead with around 40 percent working in organisation and associations, followed by

\footnotetext{
${ }^{4}$ The relatively small differences between the Scandinavian countries have not been subject to much research. The largest difference is between Denmark and Sweden, which Torp \& Lolle (2010) examine and find is accounted for primarily by differences in institutional trust and subjective well-being.
} 
Finland, Sweden, and Norway, and then with Denmark lagging markedly behind the other four Nordic countries with only around 25 percent indicating having done this. In fact, based on this indicator, organisational involvement is more pronounced in Germany (around 32 percent indicate having done this within the last year) than in Denmark. Finally, it is worth noting that the Aaland islands show a very high rate of organisational work of around 57 percent of the population (from 2010-2014), thus markedly outcompeting the other Nordic countries as the most civic on this indicator. ${ }^{5}$

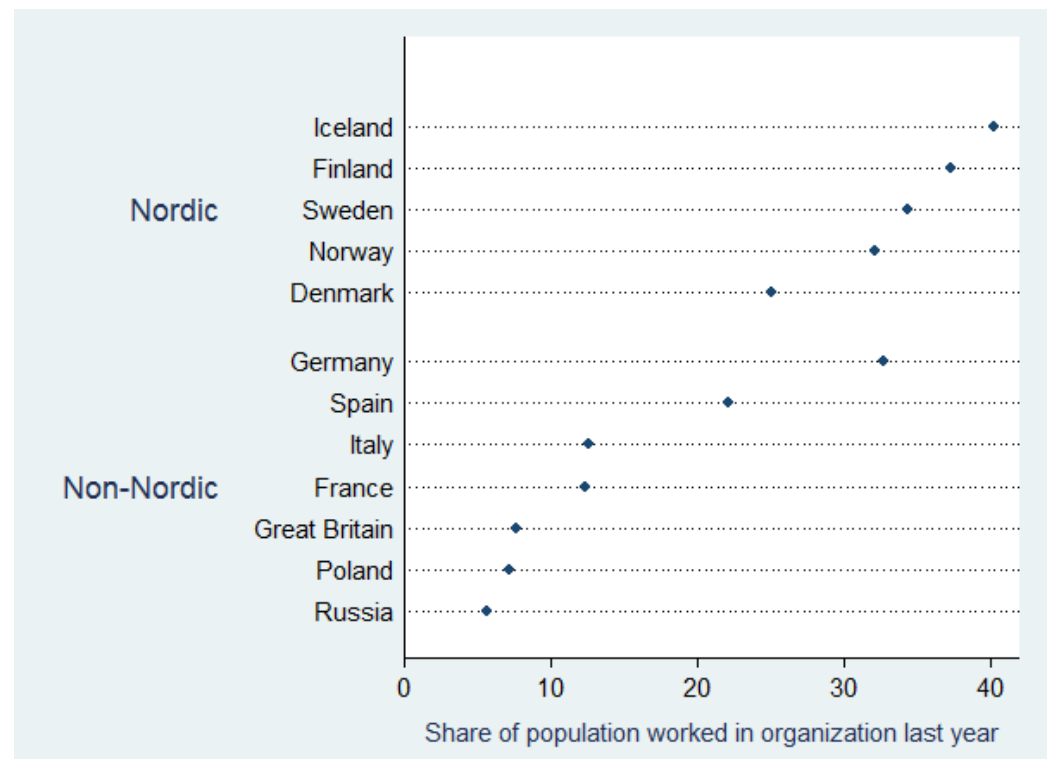

Figure 2: Work in organisations and associations in the Nordic countries and largest European countries (source: European Social Survey 2012, design weight applied).

However, one should perhaps not read too much into the observed variation in organisational work as this indicator is only one out of several frequently used indicators for engagement in civil society (others are, e.g., volunteering or sociability). Moreover, it is notoriously difficult to measure engagement in civil society because its organisation and form often varies considerably between countries.

A key to understanding Nordic civil society is the close relationship between the state and civil society (Klausen and Selle 1996; Selle 1999; Rothstein 2001; Alapuro 2005; Torpe 2011). Associational lifeespecially in youth, sports and humanitarian organisations-is highly subsidised by tax revenue. This has likely made organisational life in the Nordic countries more vibrant. Critics would claim that this may undermine their independence. In order to play the role envisaged by many proponents of social capital, associations have to be able to set limits against certain types of state action by mobilising the population. However, as Klausen and Selle put it, "The Scandinavian third sector is not working in opposition to the state; it is and has always worked together with and supplemented the state." (1996: 118). In the Danish context, Ibsen (1996) and Torpe (2011) reach the conclusion that Danish civil society remains independent, and that associations are able to act critically towards the state and the

\footnotetext{
5 This accords with other findings showing that Aaland islanders work 30 percent more volunteer hours per capita than Sweden and Finland (Kinnunen \& Rundberg 2013).
} 
politicians, who have fought for or protected their grants (see, however, Henriksen (1996) for a dissenting view).

Trägärdh (2013), based on the Swedish case, pinpoints another particularity concerning Nordic civil society. Unlike hierarchical civil society institutions such as churches, foundations, charities or even ethnic or clan-based organisations found in the US or developing countries, Nordic civil society usually has taken the form of membership-based voluntary associations with internally democratic procedures of decision-making and strong local branches (see Selle 1999 for a similar argument concerning Norwegian civil society). Hence, the Nordic countries largely share a qualitatively different, distinctive organisation of civil society that is intimately connected with the state and internally democratic with local representation.

In summary, the Nordic countries are generally high achievers in social capital as measured by social trust and civic engagement, although this is most pronounced for trust. While differences do exist between the Nordic countries, the overall picture is one of relatively high levels of homogeneity among the countries-especially when viewed through the lens of a worldwide or intra-European comparison.

\section{Intra-country variations in social capital}

While there may be limited variation in social capital between the Nordic countries, there may still be marked geographical variation within each country. Indeed, regional variation is observed in other countries-famously in Italy (Putnam, 1993), but also in the states in the United States (Fairbrother and Martin 2012).

Focusing on municipalities or very local contexts (neighbourhoods), previous studies have shown that social trust is not entirely equally distributed within Denmark, Norway and Sweden (Dinesen and Sønderskov 2012; 2015; Ivarsflaten and Strømsnes 2013; Wollebæk et al. 2012). Less research, however, have been devoted to more aggregate regional patterns within the countries, which was the focus of Putnam's (1993) path-breaking study on social capital and government performance in Italy. Figure 3 explores intra-country variation in more detail by mapping regional levels of social trust in Sweden, Norway, Denmark and Finland. ${ }^{6}$ Note that the geographical level of aggregation varies between the countries with the regions in Sweden and Finland being more disaggregated than in Norway and Denmark. While some variation exists within each country, the overall picture is one of geographic homogeneity, especially compared to the regional differences previously found in other countries. This is especially pronounced in Denmark and Norway, where the difference between the most and the least trusting regions is only 0.4 and 0.3 points on the scale from 0 to 10 , respectively.

\footnotetext{
${ }^{6}$ The measure of social trust is the same as in figure 1, but we also include data from 2010 and 2014 to increase the number of respondents in each region. Iceland is omitted for clarity of presentation. However, it consists only of the two regions (Reykjavik and the rest of Iceland), which are very similar (trust scores of 6.1 and 5.9, respectively).
} 
However, the greater variation in Sweden and Finland also reflects, ceteris paribus, the nature of the more disaggregated regional units used here. ${ }^{7}$

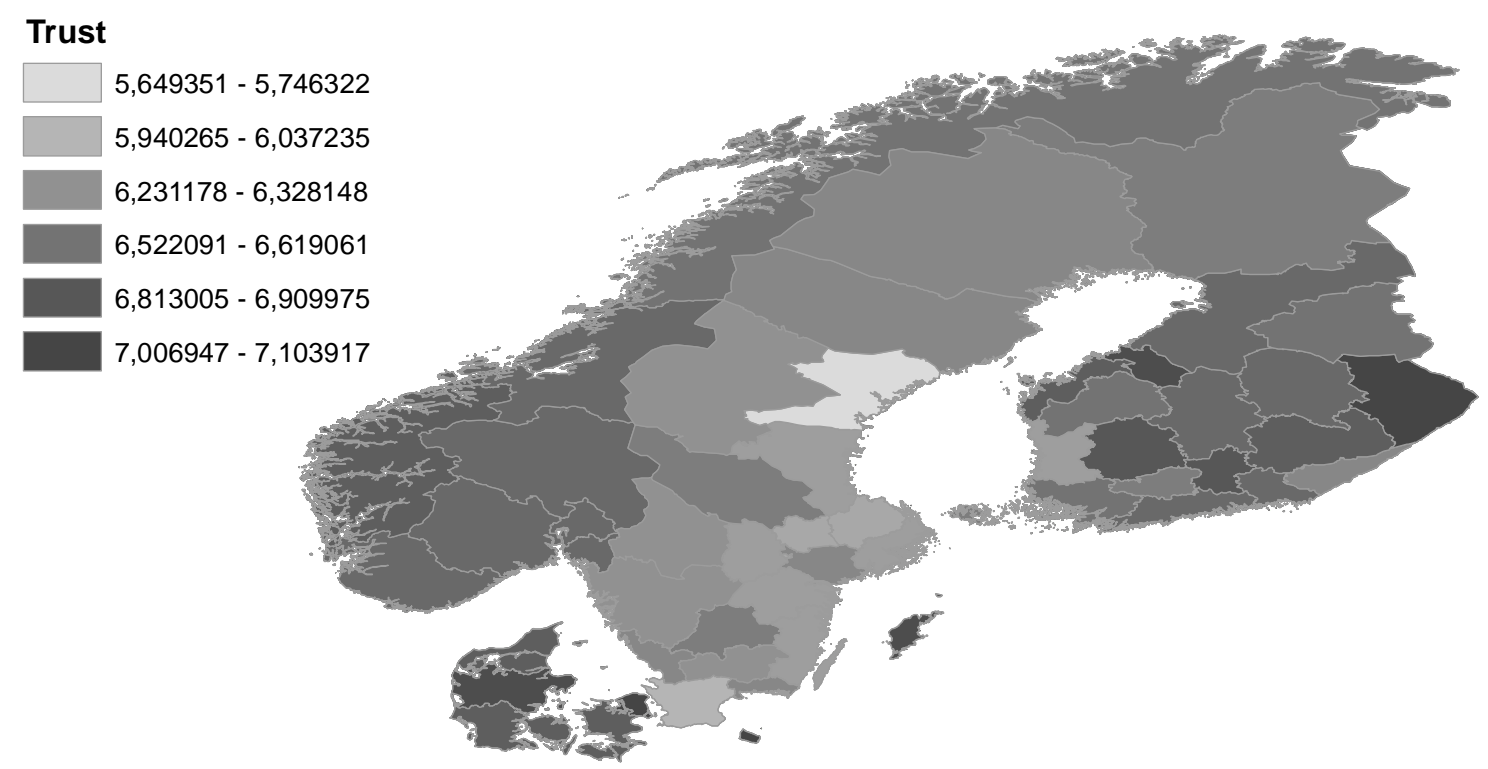

Figure 3: Social trust in the Nordic countries at NUTS 2 (Denmark and Norway) and NUTS 3 (Sweden and Finland) regional levels (source: European Social Survey 2010-2014, design weight applied).

Focusing on organisational and associational involvement (based on the measure presented above; analysis not shown), there is less internal homogeneity within each of the Nordic countries with some regions having an average level of involvement around double that of other regions in the same country. Again, this may in part reflect specific measurement, but at the same time arguably also indicates higher intra-country variation in the organisational form of social capital.

The overall picture of intra-country variation in social capital in the Nordic countries thus varies for social trust and associational involvement. For the former, we observe variation in very local contexts, but considerably more homogeneity across aggregate regional contexts. For the latter, we see greater regional variation.

\section{Social capital over time}

Having noticed that the high levels of social capital is relatively uniform among and within the Nordic countries, one may ask whether the countries have also been homogeneous in social capital over time. That is, whether the levels of social capital have been stable for long periods of time or changed more recently?

The international literature again provides an interesting backdrop. Specifically, in terms of Robert Putnam's analyses showing a marked decrease in social capital on various accounts in the United

\footnotetext{
7 The lower level of aggregation allows for a greater level of detail, and it also implies that the average for each region is based on fewer individuals, which induces larger random variation.
} 
States in the last decades of the $20^{\text {th }}$ century (Putnam 1995; 2000; Robinson and Jackson 2001). Our ability to track social capital over time in the Nordic countries (and more generally) is limited by the availability of specific indicators. This is most pronounced for social trust, which is predicated on large-scale surveys. We are therefore effectively limited to focusing on the period after the introduction of questions on trust in public opinion surveys.

Mapping the development in the level of social trust in Denmark, Sweden and Norway from around 1980 and onwards, Sønderskov and Dinesen (2014) show that trust has increased markedly in the three countries. Bäck and Kestilä (2009) show a similar trend in Finland from 1981 to 2003, although the trust measures used are not strictly comparable over time. Again, some variation exists between the countries within this overall pattern. The increase in trust is most marked in Denmark, where the share of people indicating to trust others has gone up from 47 per cent in 1979 to 79 percent in 2009. This is an unparalleled increase in trust of 32 percentage points, or 68 per cent, and, remarkably, an increase that took place from an already high level of trust, comparatively speaking. The increases in the other Nordic countries have been less pronounced. ${ }^{8}$ Nevertheless, the increase in trust in the Nordic countries stands in contrast to the trend observed in many other countries, where trust has either stagnated or seen a decline (especially in the United States, cf. Sønderskov and Dinesen 2014).

Turning to associational involvement, we can both track the development in participation by means of survey data, but also through historical records of various indicators of the vibrancy of civil society.

The second half of the 19th century is often referred to as the 'age of associations' in the Nordic countries by historians because of the increase in and importance of civil society and voluntary organisations at the time (Balle-Petersen 1976; Klausen and Selle 1996). Political liberalisation ended repression of civic life in Sweden, Norway and Denmark with the consolidation of liberal constitutions around 1850, and in Russian-ruled Finland after the accession of Alexander II in 1855 (Nordstrom 2000). While this period in the Nordic countries also saw the formation of strong philanthropy movements rooted in the middle and upper classes as in the rest of Western Europe and North America (Rothstein 2001; Gade Jensen 2011), the most important and distinctive development was of popular mass movements: the peasant movement, the labour movement, the sports movement, the religious movement and the teetotal (or temperance) movement (Klausen and Selle 1996). The organisations formed around each of these mass movements were democratic and membership-based with local branches having a great deal of influence, founding the uniquely Nordic type of associational life described in the previous section (Selle 1999; Rothstein 2001).

The peasant movement (central in Sweden and Norway, but strongest in Denmark) spawned liberal political parties, cultural associations as well as the formation of cooperatively owned folk high schools, which brought learning and liberal political ideology to the peasantry (Klaudi and Selle 1996: 105-6). Starting in the 1880s in Denmark, the movement even gave rise to economic cooperatives composed of peasants, who banded together to buy capital equipment for the processing of agricultural goods. Agricultural cooperatives quickly spread to Norway, Sweden and Finland as well (Fernández 2014).

\footnotetext{
${ }^{8}$ Over a much shorter period of time (1996-2002), Kumlin \& Rothstein (2005) show that trust has been relative stable at high levels in Sweden .
} 
The labour movement, just as the peasant movement, reflected a distinct social group and organised around trade unions and, increasingly, the national social democratic parties. The labour movement also organised its own cooperatives, cultural associations and social welfare organisations. Unlike the peasant and labor movements, the sports, religious and teetotal movements to some extent spanned class divisions. The latter two were strongest in Norway and Sweden, where they had large influence and built wide-ranging welfare institutions (Rokkan 1970). The organisations surrounding these five mass movements remained important in Sweden, Norway and Denmark until at least the 1960s.

Finland's associational life took a distinctly different trajectory from that of the Scandinavian countries. After 600 years of Swedish rule until 1809 and widespread autonomy under Russian rule for the first 90 years, the 'Russification' in 1899 curtailed Finnish self-rule, displaced the Finnish language from government, and instituted Russian censorship (Harju 2006). This led to large-scale mobilisation against Russification, including a petition gathering 523,000 signatures, one in three adult Finns, and the Great Strike in 1905 . However, civil society also became radicalised and polarised: the labour movement withdrew from civic organisations, and workers were expelled from the sports movement. After independence from Russia was proclaimed in 1917, the Reds (social democrats, trade unionists and communists) and the Whites (peasants, conservatives and industrialists) clashed violently in the civil war of 1918, which killed more than one percent of Finland's population in less than five months before the Whites' victory. The civil war deepened political polarisation, and postcivil war associational life was divided along party lines to a degree unseen in Scandinavia (Harju 2006). Repression also continued: From 1930 onward, a great number of rightist military organisations were founded, while over 3000 leftist organisations were closed down, including the largest trade unions (Harju 2006). After World War II, on the contrary, almost 3,000 associations classified as rightist were closed. Not until much later in the $20^{\text {th }}$ century did Finnish civil society again settle into the consensual form it took in the other Nordic countries.

From the 1960s onwards, organisations based around the peasant, labor, religious and teetotal movements lost ground against new types of organisations. However, the sports movement grew further. Based on studies of public registries of the total number of voluntary organisations in the Norwegian province of Hordaland, Selle and Øymyr (1992) found that from 1941 to 1988 the number of associations relative to population rose by about one third. At the same time, religious and teetotal/temperance organisations fell from more than 50 percent of associations in 1941 to only 16 percent of associations in 1988, while cultural, musical and sports clubs increased their share. Moving to the present day, Wollebæk and Segaard (2011) find that this trend continues until today in Norway. Similarly for Denmark, Torpe (2011) found that associational involvement rose from 1981 to 2008, with the largest increases in membership and activity in associations concerned with education and culture as well as in sports clubs. Since the 1960s, membership in 'ideational' associations concerned with the environment, animals, human rights and development has also risen. Unlike the traditional, Nordic membership-based organisations, however, these organisations have mostly passive members, whose only organisational activity is paying dues, and are run by professionalised secretariats rather than local, elected branches (Tranvik and Selle 2007).

Summarizing the existing evidence on the development of social capital over time, we conclude that while the Nordic countries seem to have started off from relatively high levels of social capital judged from historical data, the reservoir of social capital seems to have grown even deeper over the years - 
especially with regard to social trust. This is all the more striking given the broader international patterns described above, which generally point to either stagnation or an erosion of social capital.

\section{Why are the Nordic countries exceptional?}

The Nordic exceptionalism in social capital demonstrated above naturally raises the questions of the causes of this phenomenon. Given the ostensible importance of social capital for democratic government and the well-functioning of society more generally, this is obviously also a question of great importance from the view of policy-makers.

Mirroring disagreement in the wider literature on social capital and political culture, scholars disagree over whether high Nordic social capital should be attributed to recent social and political factors such as institutional quality, the universal welfare state or post-materialist values, or whether it instead reflects deep cultural or structural factors such as Protestantism, ethnic homogeneity, early statebuilding or the relative weakness of feudalism in Nordic societies.

Many scholars have pointed to historical evidence suggesting that the Nordic societies were marked by relative social harmony and cooperation already in the $19^{\text {th }}$ century. In a comparative perspective, present-day trust predicts the success of agricultural cooperatives in the late $19^{\text {th }}$ and early $20^{\text {th }}$ century across the world (Fernández 2014), which is taken as an indication of the persistence of trust and cooperative tendencies more generally. Putting forward perhaps the most extreme account of how very long-run historical factors may have shaped Danish culture and social capital, Svendsen and Svendsen (2010) highlight early Viking state-building and trade networks, and the trust and trustworthiness it involved, as the cause of high present-day social capital. Other evidence for "historical" explanations of Nordic exceptionalism comes from Nordic immigrants in the United States, who were perceived and portrayed as almost naïvely trusting upon their arrival in the $19^{\text {th }}$ century (Trägårdh 2009). Moreover, although their ancestors primarily emigrated in the late $19^{\text {th }}$ or early $20^{\text {th }}$ centuries, US citizens with Nordic roots are the most trusting and civically minded of all Americans, thus mirroring the relative contemporary placement of citizens in their ancestral countries in international comparisons (Rice and Feldman 1997; Uslaner 2008).

While this body of research has some merit, it may also be subject to confirmation bias. High levels of early trust may also have been present in other societies, and if this is the case, then observing high levels of cooperation and a vibrant civil society historically in the Nordic societies is a less convincing argument for high Nordic social capital today. It is also less attentive to discordant evidence such as Finland's civil war. Lastly, on a theoretical level, the mechanisms allowing earlier levels of social capital to be transmitted to the present are underspecified.

In contrast to arguments about the deep roots of Nordic social capital exceptionalism, other scholars have focused on more recent causes of high social capital. More specifically, Sønderskov and Dinesen's (2014) demonstration of the dramatic increase in trust in Denmark from 1979 to 2009 testifies to more recent drivers of social capital. They argue, and show empirically, that the increase in social trust can in part be attributed to increases in institutional trust. This ties in with the institutional account of social trust advanced by Rothstein and Stolle (2003). The argument is that high-quality institutionsespecially those related to institutional fairness (e.g. low levels of corruption)—can engender trust by 
punishing untrustworthy behaviour and espousing values of honesty. In a related, but somewhat different, vein, others have argued that the universalistic design of the Nordic welfare state (as opposed to more selective welfare programs relying more on means testing), as well as the relatively high levels of economic equality that flows from it, are the causes of high levels of social trust (Rothstein and Stolle 2003; Delhey and Newton 2005; Kumlin and Rothstein 2005; Rothstein and Uslaner 2005). Relatedly, Larsen (2007; 2013) explains the increased levels of social capital (from an already high starting point) in the Nordic countries, vis-à-vis the drop in the US and the UK, with the relative absence of a distinct underclass, which stems from low levels of inequality and the absence of mass media portrayals of character flaws of "the bottom" of society. Empirically, the remarkable similarity of Finnish levels of social capital to that of the other Nordic societies (despite its history of Russian rule, civil war and its non-Scandinavian language) provides support for the assertion that universal welfare states and low corruption increase trust. ${ }^{9}$

Finally, another institutional aspect of Nordic societies that has been highlighted as an explanation for the high levels of social capital is the predominance of 'horizontal' teaching practices in the educational system. Such teaching practices, focused on group work as opposed to teacher lectures, gained a foothold in the Nordic countries, especially after the student riots in 1968. Across and within countries, and even within the same schools, differences in such teaching practices predict differences in children's trust and cooperativeness (Algan et al. 2013).

Like the cultural and historical explanations, the institutional accounts of trust are plausible. However, given their focus on more contemporary factors, these arguments rarely address the second order question of why low levels of corruption, universalist welfare states and low economic inequality arose in the first place, and why they did so first in the Nordic countries (at least for the latter two). However, prior research provides some suggestions in this regard. One of the dominant interpretations holds that consensual democracies with proportional representation electoral systems were more likely to form the kind of 'red-green' government coalitions between workers and smallscale farmers that then pushed through universalist welfare states (Esping-Andersen 1990; Manow 2009).

Less empirical research has focused on how historical and more contemporary factors, as identified in the literature so far, have interacted. One potential example is whether high initial levels of social capital, trust in particular, in the Nordic countries helped shaped institutional choices concerning the adoption of proportional representation in the early $20^{\text {th }}$ century or crucial first steps towards the welfare state in the early or mid-20 $0^{\text {th }}$ century? The historical literature on associational life in Sweden has gone some way towards examining the latter question, showing that the early welfare state to a great extent took over work being done by bourgeois non-profit and voluntary charitable organisations (Lundstrøm 1996). The charitable organisations supported this 'nationalisation' of their work and sometimes themselves acted as instigators, and "Many of the leading persons in the charitable organisations quickly got leading positions in the governmental agencies that were established to handle the 'social question.'" (Rothstein 2001: 215). This suggests that one type of social capital contributed very concretely to building the Swedish welfare state in the post-war years. More generally, high pre-existing levels of social capital, especially trust, may also have helped protect

\footnotetext{
${ }^{9}$ The Finnish welfare state developed slightly later than the Swedish, Danish and Norwegian welfare states in partial emulation of these existing welfare states (Kettunen 2001).
} 
against problems of moral hazard inherent in welfare states without strict means-testing, or contributed to spurring strong labour movements capable of solving collective action problems. Thus, historically high social capital may have shaped the design of social policy and patterns of inequality in and of itself (Algan and Cahuc 2009), which then again feeds back positively on future social capital.

\section{Conclusion and perspectives for future research}

Are the Nordic countries exceptional in terms of social capital? The evidence reviewed in this chapter suggests that if not exceptional, they are at least high-rankers on the two dimensions of social capital-social trust and associational involvement-surveyed here. Especially for social trust, they stand out compared to other countries, while this is less pronounced for associational involvement. Moreover, while they are alike when compared to other countries, considerable variation in social capital also exists between the Nordic countries. Furthermore, the countries also vary internally, although much more in associational involvement than in trust. Finally, the nature of associational life has been, and to some extent still is, distinct in the Nordic countries as it is characterised by highly organised popular social movements with democratic internal workings.

Are the high levels of social capital long-standing features of the Nordic societies? On the one hand, there are indications that they, comparatively speaking, have had high stock of social capital back in time. That said, there is also evidence for a more recent increase in social capital over the last 30 years. Hence, from an already high starting point, Nordic social capital seems to have increased further in recent years. The question of the development of social capital over time ties in with the larger discussion of the roots of social capital and political culture more generally. At present, there is evidence suggesting both deep historical and more contemporary roots of the high levels of Nordic social capital, but none are definite, and future work integrating the two perspectives would be of great value.

Where should research on social capital in the Nordic countries look to next? In line with the broader political science literature, and ongoing research on data from the Nordic countries, we suggest three avenues for further research. First, given the exceptional quality of the public registries found in the Nordic countries, studies utilising these would further the literature on social capital not only in the Nordic countries, but more generally. Examples in recent work include precise local geographic data (Dinesen and Sønderskov 2015) and genetically informed data (Cesarini et al. 2014). Second, implementing more field experiments would be another advance in the literature because they allow for much stronger causal inference and evaluation of potential public or private interventions meant to increase social capital (see Bhatti et al. 2015 for an application in terms of turnout in Denmark). Third, and perhaps most pertinent in relation to the question of the causes of the high levels of Nordic social capital, more research utilising historical data and natural experiments to differentiate between "deep" and more contemporary causes would be very valuable. For instance, border changes have been used to estimate the effects of 19th century legal institutions (Buggle 2015) and pre-1864 Danish rule (Andersen 2015) on late $19^{\text {th }}$ century associational life in Germany, as well as the effects of historically strong Habsburg bureaucracy (Becker et al. forthcoming), and of political instability (Jancec 2013) on local trust today in Eastern Europe. Because of the Nordic countries' long histories of political stability and literacy, many historical data sources are available, yet remain underexploited. 
Thus, we believe research on Nordic social capital can remain dynamic in the coming years, and that the Nordic countries are well-placed to continue to play an outsized role in new research on social capital with relevance for the rest of the world. 


\section{Literature}

Andersen, R.F. (2015). "Nordic Social Capital Exceptionalism? Findings from the Danish-German Border Region." Mimeo.

Acemoglu, Daron, Tristan Reed, and James A. Robinson. (2014). "Chiefs: Economic Development and Elite Control of Civil Society in Sierra Leone." Journal of Political Economy, 122 (2): 319-368.

Adam, F. (2008). "Mapping Social Capital across Europe." Social Science Information, 47(2): 159-186.

Alapuro, R. (2005). "Associations and Contention in France and Finland: Constructing the Society and Describing the Society." Scandinavian Political Studies, 28(4): 377-399.

Algan, Yann, Pierre Cahuc, and Andrei Shleifer. (2013). "Teaching Practices and Social Capital." American Economic Journal: Applied Economics, 5(3): 189-210.

Algan, Yann, and Pierre Cahuc. (2009). "Civic Virtue and Labor Market Institutions." American Economic Journal: Macroeconomics, 1(1): 111-45.

Bäck, M. and E. Kestilä (2009). "Social Capital and Political Trust in Finland: An Individual-level Assessment." Scandinavian Political Studies, 32(2): 171-194.

Balle-Petersen, M. (1976). "Foreningstiden." Arv og Eje, 21: 43-68.

Berman, Sheri. (1997). "Civil Society and the Collapse of the Weimar Republic." World Politics, 49(3): 401-29.

Boix, C. and D.N. Posner (1998). "Social Capital: Explaining Its Origins and Effects on Government Performance." British Journal of Political Science, 28(4): 686-693.

Bhatti, Y.; J.O. Dahlgaard.; J.H. Hansen; and K.M. Hansen (2015). "Getting Out the Vote With Evaluative Thinking." American Journal of Evaluation, 36(3): 389-400.

Bjørnskov, C. (2008). "Social Trust and Fractionalization: A Possible Reinterpretation." European Sociological Review, 24(3): 271-283.

Bjørnskov, C. (2011). "Combating Corruption: On the Interplay Between Institutional Quality and Social Trust." Journal of Law and Economics, 54 (1): 135-59.

Buggle, J. (2015). "Law and Social Capital. Evidence from the Code Napoleon." Mimeo. Available from: http://www.johannesbuggle.com/docs/Napoleon_2:2015.pdf

Bourdieu, P. (1986). “The Forms of Capital.” In J. Richardson (Ed.) Handbook of Theory and Research for the Sociology of Education. New York: Greenwood.

Buonanno, Paolo; Daniel Montolio; and Paolo Vanin (2009). "Does Social Capital Reduce Crime?" Journal of Law and Economics, 52(1): 145-170.

Cesarini, D.;M. Johannesson; and S. Oskarsson (2014). "Pre-Birth Factors, Post-Birth Factors, and Voting: Evidence from Swedish Adoption Data." American Political Science Review, 108(1): 71-87.

Delhey, J. and K. Newton (2005). "Predicting Cross-National Levels of Social Trust: Global Pattern or Nordic Exceptionalism?” European Sociological Review, 21(4): 311-327. 
Dinesen, Peter Thisted and Kim Mannemar Sønderskov (2012). "Trust in a Time of Increasing Diversity: On the Relationship between Ethnic Heterogeneity and Social Trust in Denmark from 1979 until Today." Scandinavian Political Studies, 35(4): 273-294.

Dinesen, P.T. and K.M. Sønderskov (2015). "Ethnic Diversity and Social Trust: Evidence from the Micro-Context." American Sociological Review, 80(3): 550-573.

Esping-Andersen, Gøsta (1990). The Three Worlds of Welfare Capitalism. Princeton, N.J: Princeton University Press.

Fairbrother, Malcolm, and Isaac W. Martin (2013). "Does Inequality Erode Social Trust? Results from Multilevel Models of US States and Counties." Social Science Research, 42(2): 347-360.

Fernández, Eva (2014). “Trust, Religion, and Cooperation in Western Agriculture, 1880-1930.” The Economic History Review, 67(3): 678-98.

Gade Jensen, H. (2012). Menneskekærlighedens værk. København: Center for Politiske Studier.

Gesthuizen, M.; T. Van Der Meer; and P. Scheepers (2009). "Ethnic Diversity and Social Capital in Europe: Tests of Putnam's Thesis in European Countries." Scandinavian Political Studies, 32(2): 121142.

Hanifi, R. (2006). "Social, Cultural and Political Participation and Trust." in L. Iisakka (ed.) Social Capital in Finland. Statistical Review. Helsinki: Statistics Finland.

Harju, A. (2006). Finnish Civil Society. Helsinki: KVS Foundation.

Helliwell, J.F. and R.D. Putnam (1995). “Economic Growth and Social Capital in Italy.” Eastern Economic Journal, 21 (3): 295-307.

Henriksen, L.S. (1996). "Voluntary Organisations and Local Government. Lessons from a Danish Case Study." Voluntas: International Journal of Voluntary and Nonprofit Organizations, 7(2):177-194

Islam, M. K.; J. Merlo; I. Kawachi; M. Lindström; and U.-G. Gerdtham (2006). "Social Capital and Health: Does Egalitarianism Matter? A Literature Review." International Journal for Equity in Health, 5(3): 1475-1492.

Ivarsflaten and Strømsnes (2013). "Inequality, Diversity and Social Trust in Norwegian Communities." Journal of Elections, Public Opinion and Parties, 23(2): 322-342.

Jamal, A. (2008). Barriers to Democracy: The Other Side of Social Capital in Palestine and the Arab World. Princeton: Princeton University Press.

Jancec, M. (2012). "Do Less Stable Borders Lead to Lower Levels of Political Trust? Empirical Evidence from Eastern Europe." Mimeo.

Kennedy, B.P.; I. Kawachi; D. Prothrow-Stith; K. Lochner and V. Gupta (1998). "Social Capital, Income Inequality and Firearm Violent Crime." Social Science \& Medicine, 47(1): 7-17.

Klausen, K.K. and P. Selle (1996). "The Third Sector in Scandinavia." Voluntas: International Journal of Voluntary and Nonprofit Organizations, 7(2): 99-122.

Knack, S., and Keefer, P. (1997). "Does Social Capital Have an Economic Payoff? A Cross-Country Investigation." Quarterly Journal of Economics, 112(4): 1251-1288.

Kinnunen, J. and M. Rundberg (2013). "Volunteer work in the Aaland Islands.” Mimeo. 
Kumlin, Staffan and Bo Rothstein (2005). "Making and Breaking Social Capital. The Impact of Welfare Institutions." Comparative Political Studies, 38(4): 339-365.

Larsen, C.A. (2007). "How Welfare Regimes Generate and Erode Social Capital. The Impact of Underclass Phenomena." Comparative Politics, 40(1): 83-110.

Larsen, C.A. (2013). The Rise and Fall of Social Cohesion. The Construction and De-Construction of Social Trust in the US, UK, Sweden and Denmark. Oxford: Oxford University Press.

Lederman, D.; N. Loayza and A.M. Menéndez (2002). "Violent Crime: Does Social Capital Matter?" Economic Development and Cultural Change, 50 (3): 509-539.

Lijphart, A. (1999). Patterns of Democracy. Government Forms and Performance in 36 Countries. New Haven: Yale University Press.

Lundmark, S.; M. Gilljam; and S. Dahlberg (forthcoming). "Measuring Generalized Trust. An Examination of Question Wording and the Number of Scale Points." Public Opinion Quarterly.

Lundström, T. (1996). "The State and Voluntary Social Work in Sweden.” Voluntas: International Journal of Voluntary and Nonprofit Organizations, 7(2): 123-146.

Manow, Philip (2009). "Electoral Rules, Class Coalitions and Welfare State Regimes, or How to Explain Esping-Andersen with Stein Rokkan.” Socio-Economic Review, 7(1): 101-21.

Nannicini, Tommaso; Andrea Stella; Guido Tabellini; and Ugo Troiano (2013). "Social Capital and Political Accountability." American Economic Journal: Economic Policy, 5(2): 222-50.

Nordstrom, B.J. (2000). Scandinavia since 1500. Minneapolis: University of Minnesota Press.

Portes, A. (1998). "Social Capital. Its Origins and Applications in Modern Sociology." Annual Review of Sociology, 24: 1-24.

Putnam, R.D. (1993). Making Democracy Work: Civic Traditions in Modern Italy. Princeton, NJ: Princeton University Press.

Putnam, R.D. (2000). Bowling Alone: The Collapse and Revival of American Community. New York: Simon and Schuster.

Rice, T.W. and Feldman, J.L. (1997). "Civic Culture and Democracy: From Europe to America." Journal of Politics, 59(4): 1143-1172.

Robinson, R.V., and E.F. Jackson (2001). "Is Trust in Others Declining in America? An Age-PeriodCohort Analysis." Social Science Research, 30(1): 117-145.

Rothstein, B. (2001). "Social Capital in the Social Democratic Welfare State." Politics and Society, 29 (2): 207-241.

Rothstein, B. and D. Stolle (2003). "Introduction: Social Capital in Scandinavia." Scandinavian Political Studies, 26(1): 1-26.

Rothstein, B. and E. Uslaner (2005). "All for All. Equality, Corruption and Social Trust.” World Politics, 58(1): 41-72. 
Rothstein, B., and D. Stolle (2008). "The State and Social Capital: An Institutional Theory of Generalized Trust." Comparative Politics, 40(4): 441-459.

Satyanath, Shanker, Nico Voigtlaender, and Hans-Joachim Voth (forthcoming). "Bowling for Fascism: Social Capital and the Rise of the Nazi Party." Journal of Political Economy.

Selle, P. (1999): “The Transformation of the Voluntary Sector in Norway: A Decline in Social Capital?", in van Deth et al. (eds.) Social Capital and European Democracy. London: Routledge.

Selle, P. and B. Øymyr (1992). "Explaining Changes in the Population of Voluntary Organizations. The Roles of Aggregate and Individual-level Data." Nonprofit and Voluntary Sector Quarterly, 21(2): 147179.

Sivesind, K.H. and P. Selle (2010). "Civil Society and Social Capital in Scandinavia." In H. K. Anheier; S. Topler and R. List (eds.) International Encyclopedia of Civil Society. New York: Springer.

Sønderskov, K.M. and P.T. Dinesen (2014). "Danish Exceptionalism: Explaining the Unique Increase in Social Trust Over the Past 30 Years." European Sociological Review, 30(6): 782-795.

Svendsen, G.L.H. and G.T. Svendsen (2010). "From Vikings to Welfare: Early State Building and Social Trust in Scandinavia." Mimeo. Available from: http://extranet.sioe.org/uploads/isnie2010/svendsen_svendsen.pdf

Tabellini, G. 2010. “Culture and Institutions: Economic Development in the Regions of Europe.” Journal of the European Economic Association, 8(4): 677-716.

Torpe, L. (2011). “Foreningsdanmark.” In P. Gundelach (ed.) Små og Store Forandringer. Danskernes Værdier siden 1981. København: Hans Reitzel.

Torpe, L. and H. Lolle (2010). "Ethnic Diversity and Social Trust in Denmark and Sweden." in B. Bengtsson, P. Strömblad \& A.-H. Bay (eds.) Diversity, Inclusion and Citizenship in Scandinavia. Newcastle upon Tyne: Cambridge Scholars Press, pp. 323-344.

Tranvik, T. and P. Selle (2007). "The Rise and Fall of Popular Mass Movements: Organizational Change and Globalization - The Norwegian Case." Acta Sociologica, 50(1): 57-70.

Trägårdh, L. (2009). "Den dumme svensken och allemansrättens magi." In L. Trägårdh (ed.) Tilliten $i$ det moderna Sverige. Den dumme svensken och andra mysterier. Stockholm: SNS förlag.

Trägårdh, L. (2013). "The Historical Incubators of Trust in Sweden. From the Role of Blood to the Rule of Law." In Reuter, Marta; Filip Wijkström and Bengt Kristensson Uggla (eds.) Trust and Organizations: Confidence Across Borders. New York: Palgrave Macmillan, pp. 181-203.

Uslaner, E. (2008). "Where You Stand Depends upon Where Your Grandparents Sat." Public Opinion Quarterly, 72(4): 725-740.

Wollebæk, D. and S.B. Segaard (2011). Sosial Kapital i Norge. Oslo: Cappelen Damm Akademisk.

Wollebæk, D.; S.W. Lundåsen; and L. Trägårdh (2012). "Three Forms of Interpersonal Trust: Evidence from Swedish Municipalities." Scandinavian Political Studies, 35(4): 319-346. 
Zmerli, S., and Newton, K. (2008). "Social Trust and Attitudes toward Democracy." Public Opinion Quarterly, 72(4): 706-724. 